\title{
Some New Additions to the Avifauna of Formosa and the Island of Botel Tobago.
}

\author{
By
}

Nağamichi Kuroda, Dr. Se.

I have recently examined or known that the following eren species and subspecies of birds were collected in Formosa and the Island of Botel Tabago near the former island by Messrs. Horikawa, Kazano, Sato, Sasaki, Hirata and Tashiro. These birds are apparently new additions to the avifauna of these islands. As the form of the scops owl from the Botel Tobago seems to me to be new to science, I venture to describe about it here under the name of Otus sunia botelensis.

To all above gentlemen my best thanks are due.

\section{Motacilla alba Grandis Sharpe.}

Mr. Y. Horikawa collected an example of the wagtail at Shinten, Taihoku, N. Formosa, 17. x. 1924, and presented it to me. It is probably an adult male and measures as follows: Wing, 99 ; tail, 95.5 ; tausus, 25.5 ; entire culmen, $18 \mathrm{~mm}$. I can not find ally difference between it and a series of the form from Japan. It distributes from Hokkaido, Hondo, Shikoku, Kiusiu, Seven Islands of Izu to South Korea where only twice obtained.

\section{Jynx torquilla ? japonica Bonaparte.}

Mr. T. Kazano informod me that Mr. R. Hirata obtained a specimen at the suburb of Tainan city, 21. iii. 1927, and presented it to the Tainan Museum. The specimen has recent- 
ly examined by me and identified it to the above form with some doubt. For, it has a weaker bill and the coloration much paler and greyer. It measures as follows: Wing, 80.5; tail, 68 ; tarsus, 17 ; exposed culmen, 12.5 ; entire culmen, 16 ; bill from nostril, $10 \mathrm{~mm}$.

\section{Upupa epops saturata Lönnberg̊.}

Mr. G. Sato shot a specimen of this form at Shinten, Tailıoku, N. Formosa, date not mentioned, and presented it to me. It belongs undoubtedly to saturata, instead of orientalis, which has much darker plumage. The Taihoku Muscum keeps also an example from Giran, 5. ix. 1912, which has been reported by Dr. Ôshima and myseif under the name of "epops." ("Dôbutsu. Zasshi," XXVIII, 1916, p. 290). The latter specimen seems to me to be the same form. Mr. Kazano also informed me that he abtained an example at Shinchiku, February, 1927.

4. Otus sunia botelensis, subsp. nov.

Diagnosis:- Near to Otus sunia elegans (Cassin) in red phase of Riu Kiu Islands, but it differs from the latter by having the coloration rather more darker throughout, especially on head and breast, which are much brighter rufous with a rather distinct dark brown band across the chest, a white line above the eye washed with buffy, the loral bristles much more blackor, and in having the ear-coverts washed with rufous. The length of tail somewhat longer, 75 ( ‘?)- $-87.5 \mathrm{~mm}$. ( ㅇ?) instead of $73-79 \mathrm{~mm}$. and the wing also a trifle longer, 164 $(\delta ?)-173 \mathrm{~mm}$. ( $q ?)$ instead of $160-171 \mathrm{~mm}$. as in elegans. It also differs from 0 . sunia interpositus Kuroda of Borodino Islands, by having the wing much longer and in having the coloration of body much darker. It further differs from $O$. 
calayensis MeGrogor of Calayan in Northern Philippines, in having the chost with a rather distinct rlark brown band and by having the wing somewhat longer, 164-173 $\mathrm{mm}$. instead of $164-169 \mathrm{~mm}$. (according to MeGregor). It also differs from O. cuyensis MeGregor of Cuyo, Middle Philippines, by having the uppor tail-coverts dark brownish rufous like the back instead of clear rufous as in the latter, and in having the thighs and tarsi cinnamon with cross-lines of dark brown, instead of plain rufous brown as in cuyensis.

Type:-Adult (sex undetermined- $q$ ?), Kôtôshô or Botel Tobilgo, S. Formosil, June, 1926. S. Sasaki coll. Presented to me by Mr. Y. Horikawa. N. Kuroda collection, no. 11220.

Measurements :-Wing, $\delta$ ? 164, ㅇ? 171, 173 (type); tail,

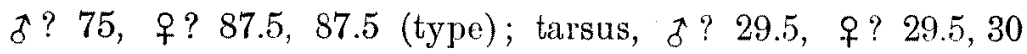
(type); middle toe and claw, $\delta ? 28$, o ? 27 (type), 28.5 ; entire culmen, $\delta$ ? 23, + ? 22 (type), 22.5; culmen without core, $\delta$ ? 14.5, ㅇ? ? 14, $14.5 \mathrm{~mm}$. (type).

Remarks:-A specimen (probably d) has its plumage paler on wing-coverts (with greyish tips to some of the coverts), scapulars and hind neck as also the under wing-coverts (pale buffy-white) and under-parts, but the mottlings are wholly equal to the two other specimens (probably of of) including the type specimen. The male (?) specimen seems to be a pale phase of the same subspecies. The new form is probably an intermediate island form between elegans and calayensis. Mr. Horikawa has recently reported on these same examples under the name of "Otus japonicus elegans" (Trans. Nat. Hist. Soc. Formosa, XVII, Aug., 1927, p. 295).

\section{Cerchneis tinnunculus perpallidus Clark.}

An adult male belonging apparently to this form was shot 
by Mr. F. Tashiro at Horisha, Middle Formosa, 12. xi. 1926, and is now preserved in my collection. It measures as follows: Wing, 214 ; tail, 169 ; tarsus, 38.5 ; culmen without cere, 14.5 min. Although the mensurements of wing and tail are rather shorter thitn those of Swann's döriesi, my specimen seems to me to be indistinguishable from the latter form, which seems also to be merely a synonym of Clark's perpallidus.

\section{Pterodroma ? hypoleuca (Salvin).}

Mr. Kazano has receutly given me a photo of the fulmar, which was obtained in Tainan City, 8. iv. 1926, after a storm, and it is now preserved in the Tainan Museum. This is apparently belonging to the above mentioned species.

\section{Anser erythropus (Linnaeus).*}

A friend of Mr. Kazino shot a specimen of the rare species near Tainan, xi. 1924, and presented it to the Tainan Museum. I have a photo of the specimen which hat given me by $\mathrm{Mr}$. Kazano.

* Mr. Horikawa has fonnd a specimen of Cygnus olo: (Gmelin) in the Taihoku Menseum. It was said to come from Tôkô (東港), Formusa, date unknown. But I have not yet examined a photo of this swan so that $I$ have exculnded it from the present list. 